\title{
Collaborative Process to Facilitate BIM-based Clash Detection Tasks for Enhancing Constructability
}

\author{
Seo, Jung-Ho ${ }^{1}$ Lee, Baek-Rae ${ }^{2}$ Kim, Ju-Hyung ${ }^{2 *}$ Kim, Jae-Jun ${ }^{2}$ \\ Department of Sustainable Architectural Engineering, Hanyang University, Sungdong-Gu, Seoul, \\ 133-791, Korea ${ }^{1}$ \\ Department of Architectural Engineering, Hanyang University, Sungdong-Gu, Seoul, 133-791, Korea ${ }^{2}$
}

\begin{abstract}
One of reasons for introducing Building Information Modeling (BIM) is to support clash detection tasks by means of a 3D product model. In the conventional construction project process, clashes have been found during construction phase. However, it can cause cost overrun and time delay. In order to investigate and correct clash detections at design phase, relevant business process and guide for this task should be provided. This study aims to identify hindrances in clash detection tasks at the design phase and analyze its current process using IDEF0 model. Despite the convenience of IDEF0 as a systems analysis tool, professional participants might have difficulties to understand their own tasks according to business process. For this reason, in this research, Business Process Model and Notation (BPMN) is introduced to provide ideal process and required decision making governance. The provide BPMN model will provide insights for a BIM-based collaborative environment to enhance the constructability through the construction project.
\end{abstract}

Keywords : building information modeling, clash detection, collaborative process

\section{Introduction}

\subsection{Research background and objective}

Since the concept of BIM (Building Information Modeling) was introduced to the construction industry in Korea, its application to Turnkey, Build-Transfer-Lease (BTL) and design-bid-build delivery methods has been on the rise. Furthermore, introducing BIM has become compulsory for public building construction projects which value is higher than KRW 50 billion since 2012. Moreover, BIM-related guidelines have been issued in invitations to tender for large-scale

\section{Received : January 12, 2012}

Revision received : April 16, 2012

Accepted : April 20, 2012

* Corresponding author : Kim, Ju-Hyung

[Tel: 82-2-2220-0304, E-mail: kcr97jhk@hanyang.ac.kr]

(c)2012 The Korea Institute of Building Construction, All rights reserved. overseas construction projects. For these reasons, the introduction of BIM in the design and construction phases has been expanded gradually, and the utilization and application of BIM is now being considered in a number of construction projects[1].

In general, BIM is introduced to the construction phase in order to improve the work efficiency by actively using a product model crated using BIM tools in the clash detection process for constructability review, quantity take-off, and in simulation for process management. Korean construction companies are now realizing that working processes should be established in order to maximize the effects of BIM utilization[2]. The BIM-based clash detection process at the construction phase plays a vital role in constructability review, both from the mock-up perspective and as a decision-making method[3]. It 
is high time for a BIM-based clash detection process to be established, as it is a function that can be highly utilized at BIM-based construction sites. However, it has been found that even in BIM-based projects, most of the clash detection process has not been yet clearly identified, or despite BIM being utilized, the working flow has not been documented. As well, many construction companies have difficulty establishing the process with their own manpower and experience[2]. In addition, from the analysis of BIM-related guidelines[4,5,6], the content for the BIM process at construction phase mainly relates to the concept and the outlined fields to which the BIM can be applied, and it is insufficient for the concrete process of the BIM-based clash detection process to be established or improved. Thus, this study aims to establish a clash detection process that can be utilized in BIM-based construction projects, and to build a system of close collaboration for efficient constructability review.

\subsection{Research Scope and Method}

To build a collaboration support system for the BIM-based clash detection process for efficient constructability review, current clash detection process conducted during design and construction phases was analyzed. The analysis targets were restricted to design-build contracts or design-construct contracts (turn-key contracts), and BIM-based construction projects in Korea were selected in which BIM was applied from the design to the construction phases. The process was generalized to exclude elements distinct to the individual projects by holding interviews with BIM-related experts (BIM coordinators, designer, general contractors, etc.).

A comparison/analysis of the clash detection processes was conducted at the design and construction phases to minimize the redundancy of clash detection, as the characteristics of the work done at the design and construction phases are similar.

The research was performed using the following procedure, and Figure 1 illustrates the research procedure.

First, to perform an analysis of clash detection at the design and construction phases in a scientific manner, the process analysis and establishment methods were compared and analyzed to select the most appropriate one.

Second, the process model was built using the selected process analysis method, and the problems in the current process were derived and their causes understood by analyzing the detailed work steps, the participants in charge, the requirements for carrying out the work, and the output of the work.

Third, the direction of the process was set in consideration of improvement opportunities related to the concept of IPD and Lean Construction and ECRS, linking to the process at the design phase, and the work schedule and procedure.

Fourth, concrete methods to improve opportunity factors were devised based on the direction of the working process, and objective and practical improvements were derived through interviews with experts.

Fifth, using the selected process building method, a process model was built that reflected improvement factors.

Finally, to verify the clash detection process at the construction phase, an FGI (Focus Group Interview) was performed, the economic benefits were reviewed, and the improvements found in the current clash detection process were documented. 


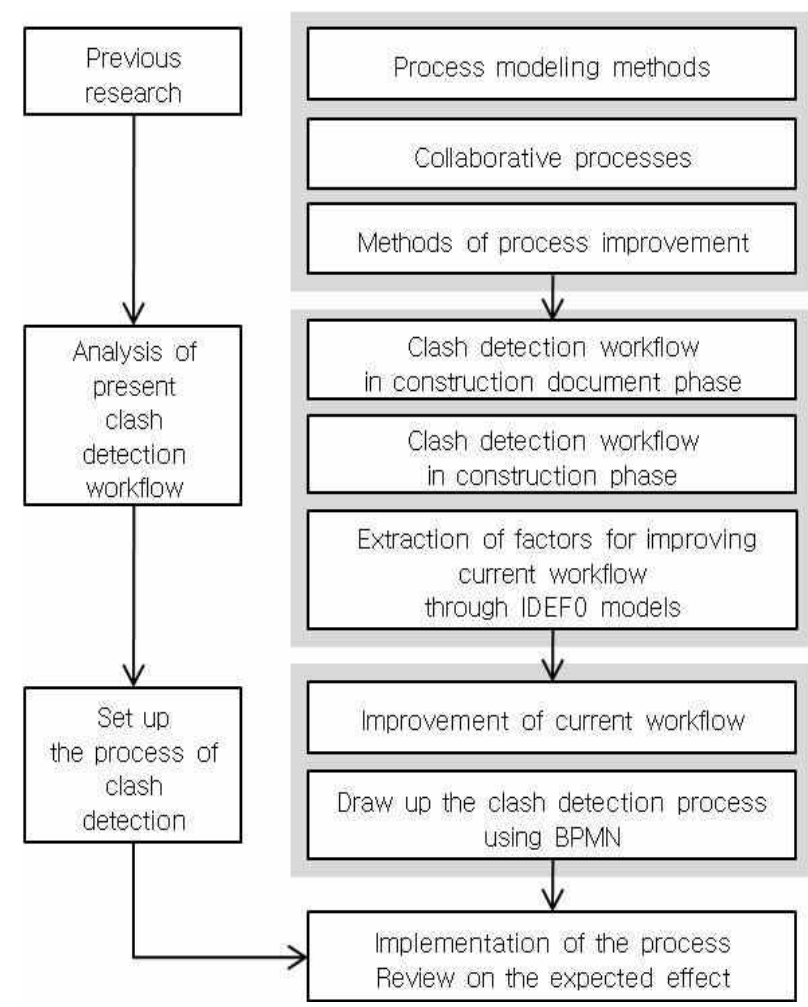

Figure 1. Research procedure

\section{Theoretical review}

\subsection{Process modeling methods}

The process modeling method should be considered in terms of the analysis and establishment of the process, since either the process building or improvement begins with an analysis of the current process.

Based on the research findings by $\mathrm{Kim}[7]$ and Kim[8], the scientific methods for process building and analysis were reviewed, including IDEFO, RAD(Role Activity Diagram), Swimlane Diagram, UML(Unified Modeling Language), and BPMN. IDEFO was selected as the analysis method of the current process that can give a detailed description of the work, the participants in charge, and the requirements and the output of work using ICOM. The process improved in this research should be flexibly used on actual construction sites, and BPMN was selected for its traits of easy usage in the establishment and management of a process, convenience of information delivery, and clear distinction by participants in charge.

The followings are the specific characteristics and the modeling methods of IDEFO and BPMN.

\subsubsection{IDEF0}

$\mathrm{IDEF}$ is a family of modeling languages developed to make a functional model of weapon manufacturing processes being funded by the U.S. Air Force, and has a hierarchical/modular/standardized structure. Not only is it appropriate for the complex processes of the construction industry, but the clear expression method is also convenient for communication between teams.

Of the languages, IDEFO is a modeling tool to specify business function from top to bottom in a simple diagram. ICOM(Input, Control, Output, Mechanism) provides an outlined description of the system as shown in Table 1, and has the advantage of being able to analyze the sub systems in detail, for which it is used in a process analysis[9].

Table 1. Properties of the IDEF0 elements

\begin{tabular}{cl}
\hline Elements & \multicolumn{1}{c}{ Properties } \\
\hline Activity & $\begin{array}{l}\text { Describe the activities/process/operations that cary } \\
\text { out the function. }\end{array}$ \\
Input & $\begin{array}{l}\text { Describe resources or data that are needed to } \\
\text { perform the function and are transformed by the } \\
\text { function into outputs }\end{array}$ \\
Control & $\begin{array}{l}\text { Describe the conditions, rules, procedures, or } \\
\text { circumstances that govem the execution of the } \\
\text { function }\end{array}$ \\
Output & $\begin{array}{l}\text { The data or objects produced when the function is } \\
\text { performed }\end{array}$ \\
Mechanism & $\begin{array}{l}\text { Define the supporting mechanisms that carry out the } \\
\text { function. } \\
\text { A mechanism may be a person, an organizational } \\
\text { unit, a physical device, or a computer program. }\end{array}$ \\
\hline
\end{tabular}




\subsubsection{BPMN(Business Process Model and Notation)}

BPMN is a modeling tool that enables various processes to be designed and mapped by distinguishing the participants from activities, and all the users provide a uniform diagram using Business Process Diagram and Swimlane Diagram from the beginning to manage a project, allowing novices to understand it easily[7].

In addition, it is widely accepted as a standardized notation for business process modeling, and there are more than 60 tools that support BPMN modeling. Moreover, several large-scale European organizations provide process management teams with BPMN training, which is used as the modeling standard[10].

Table 2 indicates the elements and notations of the BPMN.

Table 2. Elements and notations of the BPMN

\begin{tabular}{|c|c|c|}
\hline Eements & Properties & notation \\
\hline Events & $\begin{array}{c}\text { An Event is represented with a circle and } \\
\text { denotes something that happens. } \\
\text { loons within the circle denote the type of } \\
\text { event. }\end{array}$ & \\
\hline $\begin{array}{l}\text { Annotatio } \\
\text { ns }\end{array}$ & $\begin{array}{l}\text { Annotations are used to make a } \\
\text { model/diagram understandable. }\end{array}$ & \\
\hline Activities & $\begin{array}{l}\text { An activity is represented with a } \\
\text { rounded-comer rectangle, and describes } \\
\text { the kind of work that must be done. }\end{array}$ & \\
\hline $\begin{array}{l}\text { Sequence } \\
\text { Fows }\end{array}$ & $\begin{array}{l}\text { A Sequence Flow is represented with a } \\
\text { solid line and arrowhead, and shows in } \\
\text { which order the activities are performed. }\end{array}$ & \\
\hline $\begin{array}{l}\text { Message } \\
\text { Flows }\end{array}$ & $\begin{array}{l}\text { A Message Fow is represented with a } \\
\text { dashed line, an open circle at the start, } \\
\text { and an open arrowhead at the end. }\end{array}$ & \\
\hline Gateway & $\begin{array}{l}\text { A gateway is represented with a diamond } \\
\text { shape and determines the forking and } \\
\text { merging of paths, depending on the } \\
\text { conditions expressed. }\end{array}$ & \\
\hline Groups & $\begin{array}{l}\text { The group is used to group different } \\
\text { activities but does not affect the flow in } \\
\text { the diagram. }\end{array}$ & \\
\hline Pool & $\begin{array}{l}\text { Represents major participants in a process, } \\
\text { typically separating different organizations. } \\
\text { A pool contains one or more lanes. }\end{array}$ & Pool \\
\hline \multirow[b]{2}{*}{ Lane } & \multirow{2}{*}{$\begin{array}{c}\text { Used to organize and categorize activities } \\
\text { within a pool according to function or role, } \\
\text { and is depicted as a rectangle stretching } \\
\text { the width or height of the pool. }\end{array}$} & \begin{tabular}{|l|} 
Pool \\
\end{tabular} \\
\hline & & \\
\hline
\end{tabular}

\subsection{Collaborative process}

IPD and Lean were introduced as required concepts for the collaboration system building in this study to determine the direction of the clash detection process.

\subsubsection{IPD(Integrated Project Delivery)}

IPD is an integrated order placement method that operates all the elements of a project, ranging from the steps in the performance and the composition of the participants to the manner of project operation. It can be clearly differentiated from the traditional method, in which different participants deal with different activities of a project, which can be divided into planning, design, construction and maintenance.

That is, IPD aims to resolve any error or change in decision-making required at an early phase of a project such as the design phase, or in the design at the construction phase. Therefore, even though the manpower requirements are increased at the construction document phase, any error or change in design or uncertainty that might be caused at the construction phase can be prevented in advance, and the period of construction and the cost can both be reduced in the end[11].

Taking into account that the compatible information generated in the model and the various BIM-based functions are integrated in a system and shared to attain the ultimate goal of successful performance, quality, and economic feasibility of a building construction project, IPD is one of the prerequisites to maximize the effects of BIM. In other words, BIM is an essential tool for IPD implementation.

In addition, it is highly likely for the general contractor to accurately detect a 'hard clash' and correct the 'soft clash' in advance when the general contractor participates in the decision-making 
process. For instance, in the "El Camino Office Building Project in Mountain View, California, U.S.," the participation of the general contractor at the design phase was actively supported, so that his construction knowledge could be reflected. As a result, various practical effects were reported, including improvements in constructability, reduction in errors at the construction site, and establishment of a collaboration system to reduce time and expenses, to name a few[12].

\subsubsection{Lean construction}

The Lean manufacturing method was devised to reduce the inefficient factors generated when customized products are manufactured in a mass production system[13]. Lean construction is when the lean concept is applied to the construction field, and one of its key factors is that it encourages sub-contractors to participate in the decision-making process (in the design phase) and to build a collaboration system to eliminate any errors or bottlenecks in the process that compromise process efficiency[14].

The effects of this method were proven in the 'Bellevue Children's Hospital' project. Unlike the conventional practice, in which sub-contractors are asked to participate to evaluate the value engineering or design errors or to give opinions after the concept and detailed design are completed, this project avoided waste related to design changes by reflecting the suggestions of the electric and mechanical sub-contractors asked to participate at the concept design phase.

Chuck Eastman mentioned in the 'BIM handbook' that Lean and BIM could be improved together since so many parts of the two are similar, including the use of a cooperative design process to reduce wasted expenses by eliminating errors or re-work [12], and stressed that BIM should be utilized as an excellent tool for sub-contractors to introduce the Lean Construction process to the construction industry, particularly aspects of collaboration system building through the information sharing model and improvements in work efficiency through an adjustment process of unit tasks between sub-contractors.

\subsection{Process improvement method}

ECRS is one of the process improvement-related methods in 6 sigma that determines the rationality and analyzes factors to be improved based on a process model[15], and is a process of thinking from 4 different perspectives: Eliminate, Combine, Re-arrange and Simplify. "Add" is a perspective that can be added depending on the situation.

"Eliminate" is a step to find and eliminate inefficient factors in the existing process, and a thorough analysis of the objective and reasons to proceed with an activity should be performed to stop the activity.

"Combine" is a step to induce improvement effects by simultaneously performing two or more tasks or processes. At this step, the tasks or processes should be defined clearly to determine the probability of combination, and an analysis should be conducted on participants and resources to be input in advance.

"Re-arrange" is a step to change the order or realign two or more activities to induce efficiency by rescheduling the timetable of resource input.

"Simplify" is a step to identify whether the activity can be simplified, and it should be reviewed to determine why the activity has been performed as such.

Clash detection in a construction project is similar to service work, in that service is delivered in a course during which any customer's dissatisfaction and service complaint may occur. 
For this reason, it is reasonable to use ECRS as an improvement method in the clash detection process

\subsection{Process feasibility review method}

\subsubsection{FGI}

FGI(Focus Group Interview) is one of the quality research methods used to elicit results through a general discussion on the research objective-related issues with a small group of people(7-8) who can represent the research target.

The samples considered to be experts are selected and have a discussion on the research objective-related issues so that more useful information can be obtained through an FGI than through an individual interview. The objective of an FGI is to identify unexpected information related to the research objective through a natural conversation among interviewees, as well as responses to the official questionnaire that were unexpected.

\section{Analysis of clash detection in current projects}

To analyze the workflow or clash detection at the construction document and construction phases in current projects, A Projects were selected as targets because they are turn-key contracts in which a BIM model is applied from the construction document to current construction phase. In the analysis, the aim was to identify improvements by comparing work processes in the construction document and construction phases.

In addition, the clash detection was generalized through interviews with BIM-related experts to eliminate elements distinct to individual research targets.

\subsection{Analysis of clash detection in the construction document phase}

Figure 2 indicates the clash detection workflow in the construction document phase.

Clash detection at the construction document phase is performed to eliminate clashes between members when the BIM model is integrated into each part, including construction, structure and MEP.

Based on the generalized clash detection at the construction document phase, activities were specified by phase, and Table 3 shows the Input and Control required in each activity, the Output from the activity performed, and the Mechanism.

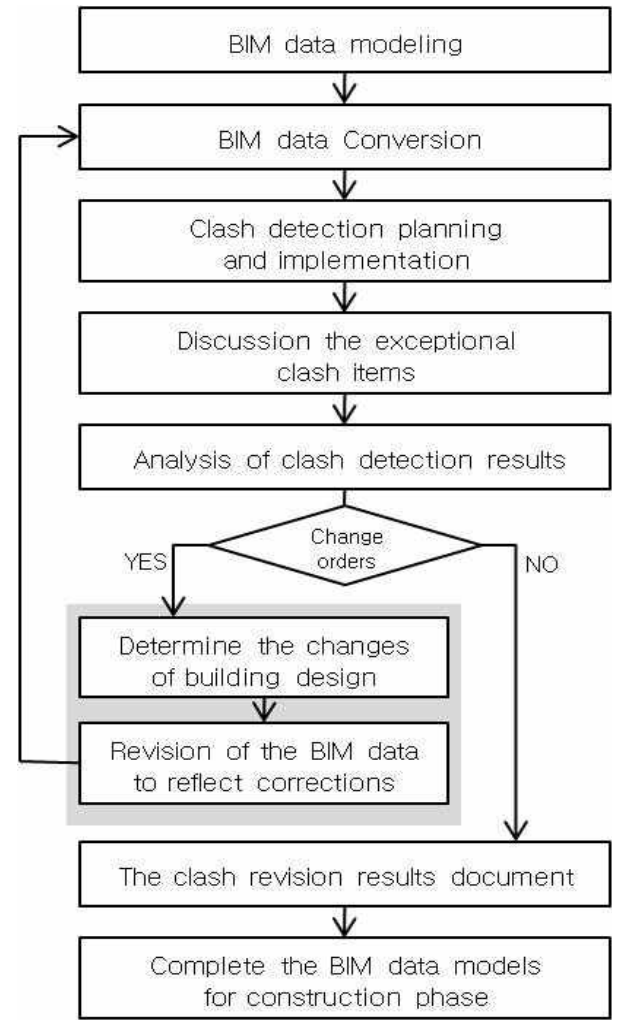

Figure 2. Clash detection workflow at the construction document phase

\subsection{Analysis of clash detection at construction phase}

Figure 3 illustrates the clash detection workflow 
Table 3. ICOM of clash detection at the construction document phase

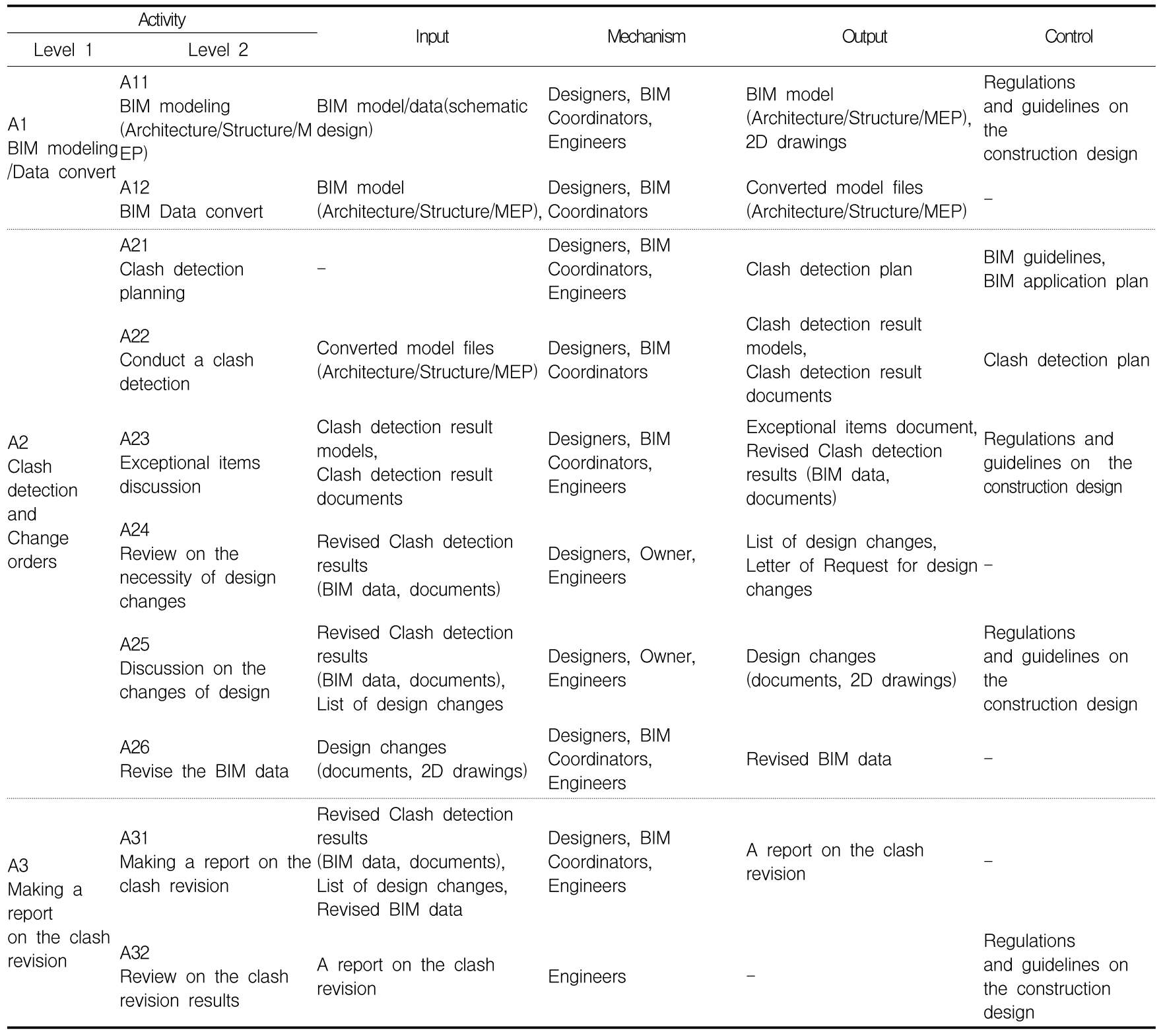

at the construction phase. Clash detection is performed by experts to identify any clash in the event of a design change or any clash between work types/processes/equipment for constructability review, as well as arising from the 3D model simulation conducted at the construction document phase.

Clash detection at the construction document phase puts an emphasis on improving the completeness of the document to be delivered, while clash detection at the construction phase places an emphasis on the completeness of the structure itself by utilizing the actual results of the constructability review.

In addition, based on the generalized clash detection at the construction phase, the analysis results of IOOM by phase (specification of activities, the party in charge of the activity, requirements or constraints by activity and output of the activity done) are indicated in Table 4. 


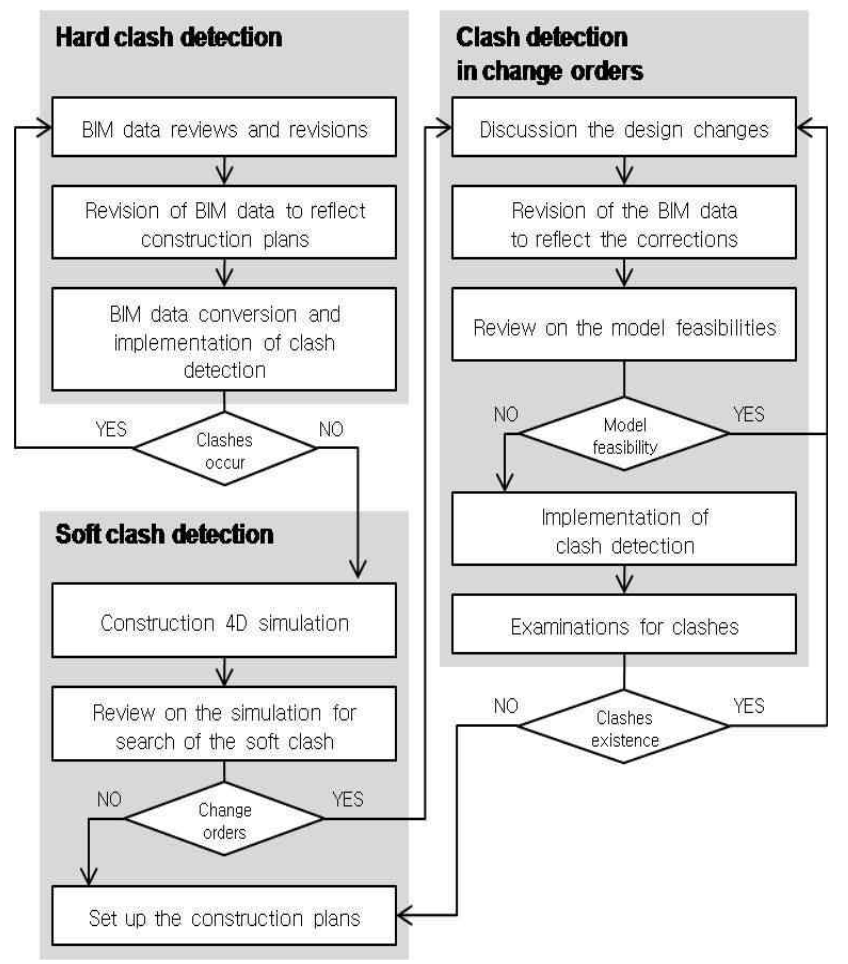

Figure 3. Clash detection workflow at construction phase

\subsection{Problems and improvements of the current clash detection}

\subsubsection{Redundancy of 'hard clash' confirmation}

There are two types of clashes found in BIM-based clash detection: hard clashes and soft clashes. A 'hard clash' is the overlapping of members of the BIM model in a space. A 'soft clash' is a design error that is a failure to secure sufficient space for other parts, including access, insulation and safety.

In the construction document phase, a BIM model is built for construction, structure $\mathrm{MEP}$ (machine/fire resistance/electricity) and then it is determined whether or not there is any 'hard clash' between construction-structure/construction-MEP/structure-M EP using clash detection software (including Navisworks of Autodesk, Solibi Model Checker of Solibri).

At the construction phase, the aim of clash detection is to identify 'soft clash' for constructability review, which requires 'hard clash' detection as a prerequisite. The 'hard clash' can be skipped only when the clash detection done at the construction document phase is entirely reliable.

It is revealed that in actual cases where the project base point (the coordination set to integrate BIM for each field into one) does not coincide between models, it is impossible to create an integrated model and perform the clash detection; or, the 2D drawings do not match the BIM models. In those cases, it is necessary to check for "hard clashes' again.

It is necessary to check for 'hard clashes' at the construction phase is because a construction document BIM model does not reflect the construction plan, including the Zoning plan and the member classification system. To utilize a BIM model at the construction phase, it is inevitably necessary to make some adjustments for the model, and the 'hard clash' should be checked again, which delays the utilization of the BIM for some period of time and the effects of 'soft clashes' and constructability review.

In 'ICOM analysis' by phase and 'clash detection workflow in sections 3.1 and 3.2 , the way to repeat the "hard clash' check that has already been performed at the construction document phase in the construction phase is discussed.

\subsubsection{Collaboration level of participants in clash detection}

Figures 4 and 5 indicate [A2] level of clash detection performed at the construction document and construction phases, where Mechanism was extracted from the ICOM components for IDEFO.

The participants in clash detection at the construction document phase include experts in the professional fields (i.e. construction, structural engineering and MEP), BIM coordinators, and client. This shows that all experts except for the project client participated in almost every activity 
Table 4. ICOM of clash detection at the construction phase

\begin{tabular}{|c|c|c|c|c|c|}
\hline \multicolumn{2}{|r|}{ Activity } & \multirow{2}{*}{ Input } & \multirow{2}{*}{ Mechanism } & \multirow{2}{*}{ Output } & \multirow{2}{*}{ Control } \\
\hline Level 1 & Level 2 & & & & \\
\hline $\begin{array}{l}\text { A1 } \\
\text { Review and } \\
\text { revision of } \\
\text { the BIM } \\
\text { data }\end{array}$ & $\begin{array}{l}\text { A11 } \\
\text { Review and revision } \\
\text { of the BIM data }\end{array}$ & $\begin{array}{l}\text { BIM data/models, } \\
\text { A report on the clash detection and } \\
\text { revision, } \\
2 \mathrm{D} \text { drawings (construction document } \\
\text { phase) }\end{array}$ & $\begin{array}{l}\text { BIM } \\
\text { Coordinator, } \\
\text { General } \\
\text { contractor }\end{array}$ & Reviews on the BIM data & BIM data checklist \\
\hline \multirow{4}{*}{$\begin{array}{l}\text { A2 } \\
\text { Revise the } \\
\text { BIM data } \\
\text { and } \\
\text { clash } \\
\text { detection }\end{array}$} & $\begin{array}{l}\text { A21 } \\
\text { Revise the BIM data } \\
\text { to reflect the } \\
\text { construction plan } \\
\text { ?2? }\end{array}$ & $\begin{array}{l}\text { BIM data/model } \\
\text { (construction document phase) }\end{array}$ & $\begin{array}{l}\text { BIM } \\
\text { Coordinator }\end{array}$ & $\begin{array}{l}\text { Revised models reflecting } \\
\text { construction plan }\end{array}$ & The construction plan \\
\hline & $\begin{array}{l}\text { A22 } \\
\text { Conduct a clash } \\
\text { detection of revised } \\
\text { models }\end{array}$ & $\begin{array}{l}\text { Revised models reflecting } \\
\text { construction plan }\end{array}$ & $\begin{array}{l}\text { BIM } \\
\text { Coordinator }\end{array}$ & $\begin{array}{l}\text { Clash detection result } \\
\text { models, } \\
\text { Clash detection result } \\
\text { documents }\end{array}$ & - \\
\hline & $\begin{array}{l}\text { A23 } \\
\text { Review } \\
\text { on the design } \\
\text { changes }\end{array}$ & $\begin{array}{l}\text { Clash detection result models, } \\
\text { Clash detection result documents }\end{array}$ & $\begin{array}{l}\text { Engineers, } \\
\text { General } \\
\text { contractor }\end{array}$ & List of design changes, & $\begin{array}{l}\text { Regulations } \\
\text { and guidelines of the } \\
\text { construction code }\end{array}$ \\
\hline & $\begin{array}{l}\text { A } 24 \\
\text { Discussion on the } \\
\text { changes of design }\end{array}$ & $\begin{array}{l}\text { Revised Clash detection results } \\
\text { (BIM data, documents), } \\
\text { List of design changes }\end{array}$ & $\begin{array}{l}\text { Owner, } \\
\text { Engineers }\end{array}$ & $\begin{array}{l}\text { Design changes } \\
\text { (documents, 2D drawings) }\end{array}$ & $\begin{array}{l}\text { Regulations } \\
\text { and guidelines of the } \\
\text { construction code }\end{array}$ \\
\hline \multirow{4}{*}{$\begin{array}{l}\text { A3 } \\
\text { Construction } \\
\text { simulation } \\
\text { for soft } \\
\text { clash } \\
\text { detection }\end{array}$} & $\begin{array}{l}\text { A31 } \\
\text { Construction 4D } \\
\text { simulation }\end{array}$ & BIM models for construction & $\begin{array}{l}\text { BIM } \\
\text { Coordinator }\end{array}$ & $\begin{array}{l}\text { Construction 4D simulation } \\
\text { (VOD, models, reports) }\end{array}$ & $\begin{array}{l}\text { Contract document, } \\
\text { Time schedules of } \\
\text { work, } \\
\text { Temporary plan, } \\
\text { Material lifting operation } \\
\text { plan }\end{array}$ \\
\hline & $\begin{array}{l}\text { A32 } \\
\text { Review on the } \\
\text { simulation for search } \\
\text { of the soft clash }\end{array}$ & $\begin{array}{l}\text { Construction 4D simulation } \\
\text { (VOD, models, reports) }\end{array}$ & $\begin{array}{l}\text { BIM } \\
\text { Coordinator, } \\
\text { General } \\
\text { contractor }\end{array}$ & $\begin{array}{l}\text { Clash detection result } \\
\text { (reports, models) }\end{array}$ & 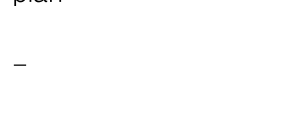 \\
\hline & $\begin{array}{l}\text { A33 } \\
\text { Review on the } \\
\text { necessity of design } \\
\text { changes }\end{array}$ & $\begin{array}{l}\text { Clash detection result } \\
\text { (reports, models) }\end{array}$ & $\begin{array}{l}\text { Engineers, } \\
\text { General } \\
\text { contractor }\end{array}$ & $\begin{array}{l}\text { List of design changes, } \\
\text { Letter of Request for design } \\
\text { changes }\end{array}$ & - \\
\hline & $\begin{array}{l}\text { A34 } \\
\text { Discussion on the } \\
\text { changes of design }\end{array}$ & $\begin{array}{l}\text { Clash detection result(reports, } \\
\text { models), } \\
\text { List of design changes }\end{array}$ & $\begin{array}{l}\text { Owner, } \\
\text { Engineers }\end{array}$ & $\begin{array}{l}\text { Design and construction plan } \\
\text { changes (documents, 2D } \\
\text { drawings) }\end{array}$ & $\begin{array}{l}\text { nRegulations } \\
\text { and guidelines of the } \\
\text { construction code }\end{array}$ \\
\hline \multirow{4}{*}{$\begin{array}{l}\text { A4 } \\
\text { Change } \\
\text { orders and } \\
\text { clash } \\
\text { detection }\end{array}$} & $\begin{array}{l}\text { A41 } \\
\text { Revise the BIM data }\end{array}$ & $\begin{array}{l}\text { Design and construction plan } \\
\text { changes } \\
\text { (documents, 2D drawings) }\end{array}$ & $\begin{array}{l}\text { BIM } \\
\text { Coordinator }\end{array}$ & $\begin{array}{l}\text { Revised BIM data for } \\
\text { construction }\end{array}$ & - \\
\hline & $\begin{array}{l}\text { A42 } \\
\text { Check the validity of } \\
\text { models } \\
\text { A43 }\end{array}$ & $\begin{array}{l}\text { Revised models reflecting } \\
\text { construction plan, } \\
\text { Revised BIM data for construction }\end{array}$ & $\begin{array}{l}\text { General } \\
\text { contractor }\end{array}$ & $\begin{array}{l}\text { Report on the feasibility of } \\
\text { design changes }\end{array}$ & - \\
\hline & $\begin{array}{l}\text { BIM Data convert and } \\
\text { conduct a clash } \\
\text { detection }\end{array}$ & Revised BIM data for construction & $\begin{array}{l}\text { BIM } \\
\text { Coordinator }\end{array}$ & $\begin{array}{l}\text { Clash detection result } \\
\text { (reports, models) }\end{array}$ & - \\
\hline & $\begin{array}{l}\text { A44 } \\
\text { Examinations for } \\
\text { clashes }\end{array}$ & $\begin{array}{l}\text { Clash detection result(reports, } \\
\text { models) }\end{array}$ & $\begin{array}{l}\text { Engineers, } \\
\text { General } \\
\text { contractor }\end{array}$ & $\begin{array}{l}\text { Reports on the clash } \\
\text { detection results, Letter of } \\
\text { Request for design changes }\end{array}$ & - \\
\hline $\begin{array}{l}\text { A5 } \\
\text { Set up the } \\
\text { construction } \\
\text { plans }\end{array}$ & $\begin{array}{l}\text { A51 } \\
\text { Set up the } \\
\text { construction plans }\end{array}$ & $\begin{array}{l}\text { Reviews on the clash detection } \\
\text { results, } \\
\text { Letter of Request } \\
\text { for design changes }\end{array}$ & $\begin{array}{l}\text { Engineers, } \\
\text { General } \\
\text { contractor }\end{array}$ & $\begin{array}{l}\text { Time schedules of work, } \\
\text { Safety management plans, } \\
\text { Quality control processes, } \\
\text { Temporary plans, Material } \\
\text { lifting operation plans }\end{array}$ & - \\
\hline
\end{tabular}

of the clash detection process.

On the other hand, the participants in clash detection at the construction phase include additional experts from general contractor, but experts from one or two specific fields were assigned to conduct the activities of the clash detection process.

This means that clash detection involves less collaboration at the construction phase than that at the construction document phase, which indicates that there is a high potential for the factors considered in the performance of each 
activity to be ignored. In other words, trial and error and rework of each of the activities is highly likely.

Of course, it might not be efficient or desirable for all participants to participate in every activity. Nonetheless, it is efficient to encourage all the participants to participate in the decision-making for each of the activities, to the extent that it is conducive to preventing any error that may occur in the future, which also coincides with the concept of IPD and Lean.

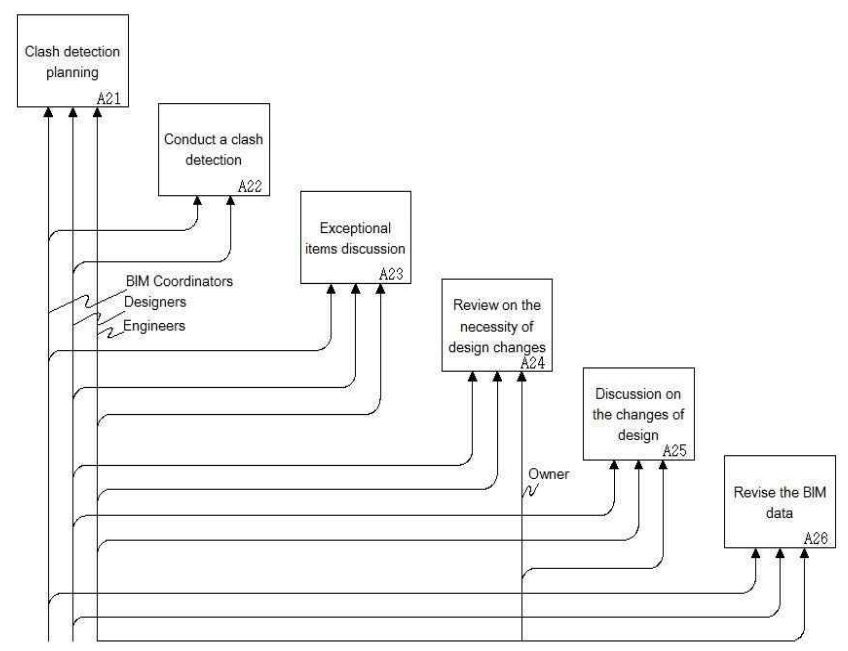

Figure 4. Clash detection participants at construction document phase[A2]

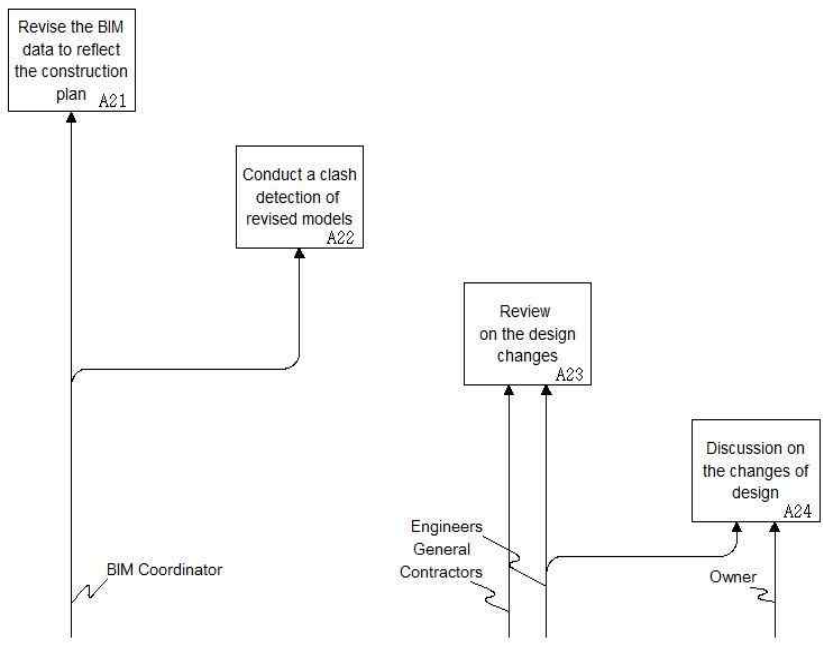

Figure 5. Clash detection participants at construction phase[A2]

\section{Process for the establishment of a collaboration system}

\subsection{Improvement plan for the current clash detection}

\subsubsection{Participation of general contractor in the design phase}

The concept of IPD mentioned in 2.2.1) can be one of the important factors to set the direction for clash detection. The effects of IPD by focusing resources on the early stage of the project can be attained in the condition of collaboration among participants. Collaboration can be maximized when a BIM model is used as an information sharing tool. In order words, BIM-based collaboration is a prerequisite for creating the effects of IPD. For this reason, a BIM-based clash detection process should be built as a tool for collaboration.

As noted in 3.3, the most noticeable problem in the current tasks for detecting clash is the redundancy of 'hard processes' at the construction document and construction phases. It usually takes a considerable period of time to do the activity, and as a result the utilization of a BIM model is delayed at the construction phase.

To reduce such delay, it may help to reschedule the timetable for participants in the 'hard clash' check at the construction phase to participate in the construction document phase.

While the 'hard clash' check at the construction phase should be performed due to the uncertainty of the output at the construction document phase and some changes in the model utilized at the construction phase, the 'hard clash' check can be eliminated if the participants in the 'hard clash' check help create a BIM-based model reflecting the construction plan, including the zoning plan and WBS(Work Breakdown Structure), at the construction document phase, and perform the 
'hard clash' check.

Unlike the traditional process, which divides the roles of a construction project by phase, the expansion of the role of participants in clash detection at the construction phase coincides with the idea of IPD to minimize the design errors in the subsequent phases by applying more resources in an early phase of the project, which can be the underlying condition to maximize the effects of a BIM model.

\subsubsection{Expansion of participants and participation in an early phase}

The relationship between Lean Construction and BIM should be considered in setting the direction for clash detection. BIM-based collaboration support facilitates the realization of the core concept of Lean, which is to eliminate any error or bottleneck in the process that impedes the working efficiency by building a collaboration system in which sub-contractors in sub-tiers participate, which can be drawn from the idea discussed in 2.2.

Therefore, to address the low level of collaboration between participants shown in 3.3, a process should be established to induce as many participants to collaborate with one another as possible, and to actively participate in the process as well.

Moreover, the clash detection process should be designed to induce sub-contractors who handle the clash detection at the construction phase to participate. In addition, they should participate in an early phase of the construction document.

The most beneficial effect of utilizing a BIM-model can be obtained when the specific activities by sub-contractors are done in accordance with a construction model and through a delicate adjustment. By doing this, clash detection can be performed more accurately, and a correction can be also made for the clash in question.

Early participation in clash detection in the design phase is also an important element in improving the current clash detection process. When discussing the intention of the sub-contractors in charge of a detailed activity with the designer, errors that may exist in the current design plan are likely to be found, including 'hard clashes' in the BIM model and 'soft clashes' arising from problems such as constructability.

In addition, to build a more effective collaboration system, 'Kaizen Event' is a prerequisite to the Activities comprising the process. The Kaizen Event is a concept of Lean Construction, and is a short, focused project aiming to discuss reengineering of the working manner and give motivation to prompt, continual improvement of ongoing design and construction processes[12]. As in Korean construction sites where meetings are held using a BIM model at the place called ' $\mathrm{i}-\mathrm{ROOM}$,' the environment for collaboration should be built using the Kaizen Event because the clash detection process presented in this study is focused on collaboration through smooth information sharing among participants.

\subsubsection{Specification of working process and addition of an activity}

The concept of ECRS discussed in 2.3 was applied to analyze the problems of the process. From the research findings, it is revealed that the process was not as specified and concrete as in the construction document phase. To address these problems, various activities need to be added to the clash detection process at the construction phase, including 'clash check plan,' 'deliberation on what to exclude from the clash review, 'drawing-up and review of the correction result 
report to clash,' and 'drawing-up of checklist and model check of the construction document model.'

The 'clash check plan' is an activity to select software appropriate for clash check and to schedule the order and combination of BIM models for the process to detect clashes, which means it is the process of drawing up an effective clash checking schedule for the given condition.

'Deliberation on what to exclude from clash review' is an activity to select effective clash factors from redundant factors in the simple model-objects detected by a clash detection tool. Since it has a limit in that the "hard clash' of a BIM model detected by the clash check tool is accompanied by ineffective clash depending on the modeling method, engineers from each field should review and screen them in person, which can be a wasteful factor for the process. Therefore, with the factors to be excluded from the process documented clearly, quasi-clash factors that could be found in subsequent projects would be effectively classified. In addition, this activity should be applied to check 'soft clash' using construction simulation, and clash detection should be performed by the General Contractor, BIM Coordinator and Engineers in collaboration with sub-contractors at a more detailed level.

'Drawing-up and review of the correction result report to clash' is an activity that is required to deal with a quasi-situation of clash detection at the construction phase, such as 'deliberation on what to exclude,' and participants should share sufficient information regarding the reviewing factors.

'Drawing-up of checklist and clash check of the construction document model' involves drawing up a checklist for construction phase (whether the project base point of models are identical, whether the models are matched with the 2D drawings, etc.) when the construction company and the sub-contractors did not collaborate in the design phase. That is, it is an activity to determine the reliability of a BIM model created in the construction document through a comparison between the model and the result. This activity requires active participation and sufficient information sharing by the designers in each field as well as by the general contractor and BIM Coordinator who participate in the phase, and it can be an alternative to prevent redundant checks of 'hard clash' discussed in 3.3.

\subsection{Setting up a BPMN-based collaboration system for clash detection}

A concrete improvement plan drawn from the clash detection process was discussed in 4.1 , and Figure 6 shows the clash detection process BPMN diagram.

One of the advantages of this process is that the general contractor participates in and manages an early phase of the construction document to create a product model by using BIM tools, to conduct clash detection between products in different activities, and to correct any clashes found. This helps eliminate the need for repeated performance of the 'hard clash' detection process at the construction phase by adding construction plan, Zoning plan, and WBS to the BIM-based construction document phase, which allows the BIM model to be applied in an early construction phase. As a result, it can be expected that constructability review and BIM-based collaboration support are performed more smoothly than before.

Next, sub-contractors participate at the construction phase to review a BIM model and simulation, perform clash detection, exclude factors from the clash detection and deliberate on the corrections to clashes. The participation expands even to the construction document phase. The 


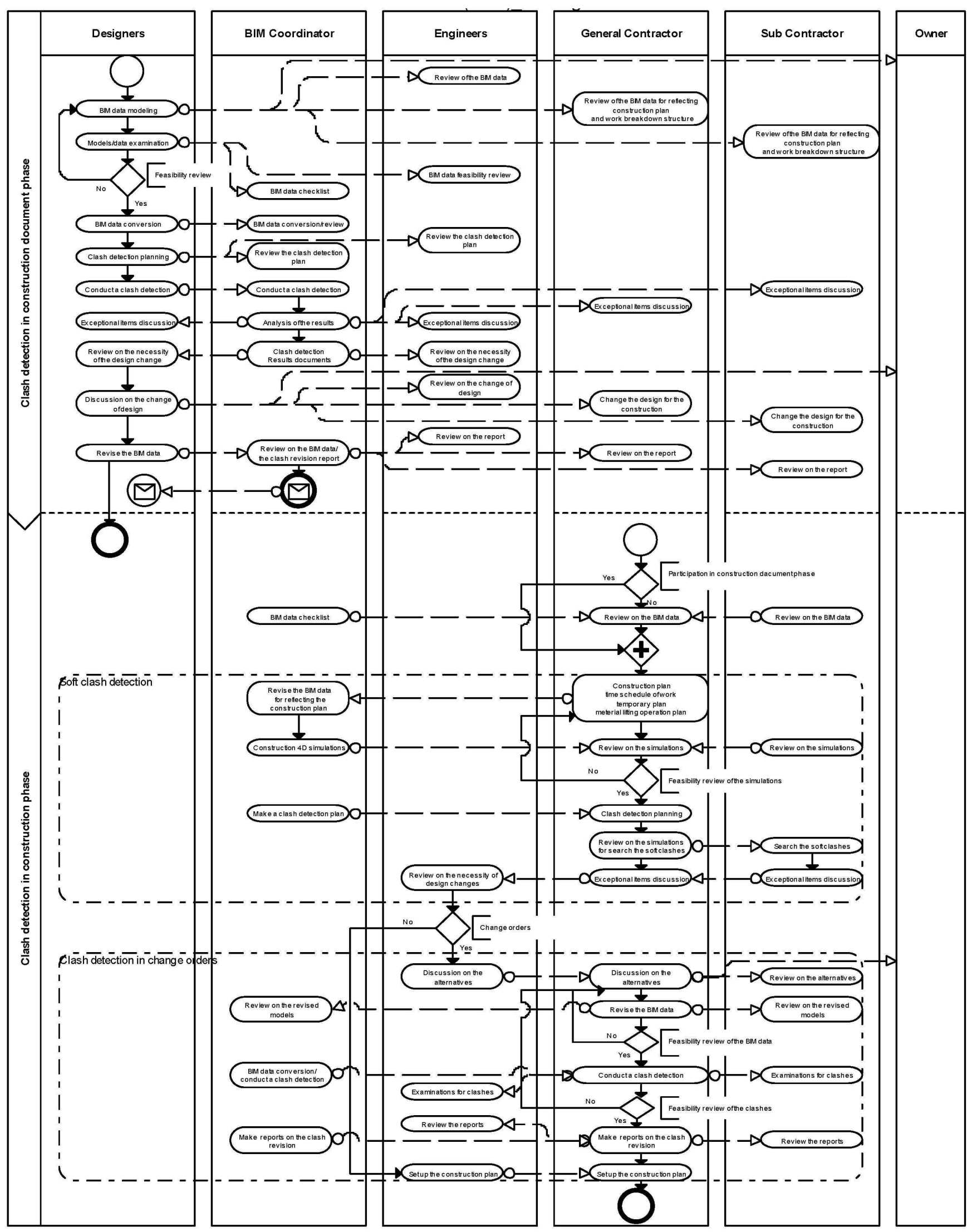

Figure 6. Clash detection process BPMN diagram 
most significant advantage is that sub-contractors perform specific parts of their work using BIM models. When more active participation and delicate adjustment between participants is achieved, it enables a more accurate and detailed clash detection to be conducted, while checking for 'soft clash.' In addition, ETO(Engineered-To-Order) is expected to reduce design errors and facilitate smooth installation at the actual construction site.

Moreover, the activities that have been added to the existing clash detection process, including 'clash check plan,' 'deliberation on what to exclude,' 'drawing-up and review of correction result report to clash,' and 'drawing-up of checklist and model check of construction document' can prevent errors in future projects, since the factors to be excluded from clash and the correction results are saved in the database. BIM-based constructability review and a smoother engineering process can be expected as a result of a more systematic clash check at the construction phase.

\subsection{Feasibility review}

\subsubsection{FGI Analysis}

To do a feasibility review and assessment of the clash detection process, an FGI was conducted. To secure objectivity, the interviewees were 12 experts with at least 3 years of experience in BIM projects in 7 fields (designer/construction/structure/MEP/ coordinator/consultant/research) and practical experience in clash detection in the design/construction phase.

With the expert panel, we held a discussion for more than 3 hours on a number of issues including the possibility of problem-solving in the process and its feasibility, the validity of activities and the Kaizen Event, and realistic problems.

\subsubsection{Feasibility review based on the analytical results of the FGI}

Based on the analytical results of the FGI, all experts mentioned that with more active participation of the general contractor in clash detection in the design phase, higher reliability of the design model can be obtained when using a BIM-model at the construction phase. More than 10 out of 12 experts thought participation of the General Contractor in the design phase could minimize the 'hard clash' caused by model changes (construction plan, WBS, zoning plan, etc.) due to the utilization of a BIM model at the construction phase. However, they also pointed out that if the general contractor participated in the design phase, it could lead to problems such as protraction of the design process due to inclusion of the data of the general contractor, and additional expenses due to new tasks being required.

On the issue of building a collaboration system for the active participation of sub-contractors, 11 experts expected clash detection to be enhanced to more detailed levels, which helps reduce re-construction, and curtails costs and the construction period accordingly. However, to achieve this in reality, a working environment that induces collaboration must first be formed, a manager of information sharing between participants should be employed, and an initial investment is required to solve the increasing expenses arising from BIM training.

In addition, while participation of the general contractor and sub-contractors in the design phase is possible in a turn-key contract, it is noted as a drawback that it is difficult to apply such a collaboration system to the process in current design-bid-build type projects.

There were opinions related to the 'establishment of a clash detection plan' including the participation of all experts in selecting the most appropriate 
clash detection tool in the clash detection process of construction phase, and the combination of BIM-based clash detection processes for each field. According to pilot projects, it is necessary to determine the scope of clash detection tasks. Essential aspects among clashes must be identified by professionals in previous and thus they can react properly to later similar clash items with clear guide.

Although 10 experts responded positively to 'drawing-up of correction result report to clash' in that the engineering process is converted into a database, it is also noted that time and HR should be invested in clash detection, and that it should be shared beyond drawing-up and review.

'Drawing-up of checklist and model check of the construction document model' is a prerequisite for the utilization of BIM data at construction phase. To achieve this in reality, the requirements of the general contractor and Owner should be clearly identified, and the factors to evaluate these should be selected carefully. Also, 6 of the experts considered that there are restrictions in terms of the capacity of the general contractor to evaluate all design-and-engineering-related factors and processes. It is hard to assess reliability accurately, because different participants perform different tasks in a process.

10 experts responded that Kaizen Event can be a highly active communication method between participants in clash detection, which may help identify the unstructured factors in drawings, specifications or flowcharts. However, the clear timetable and frequency appropriate for the project should be specified, and two of the experts even responded that it was not necessary because the additional initial expenses and time consumption could not be justified.

\section{Conclusion}

In recent years, the cases of BIM-based construction projects have been reported; however, in general, they were pilot projects to boost the utilization of product models that introduced BIM tools rather than to gain real benefits of BIM in terms of reduction in expenses and construction period. We are still at the early stages of introducing the BIM model, and a BIM-based work process is needed to improve related work processes.

Therefore, in this paper a BIM-based clash detection process was presented, and a plan to raise the efficiency of clash detection was discussed as part of a plan to activate the BIM-based review process for engineering and constructability at the construction phase, and the establishment of a BIM-based collaboration support environment.

The findings of this research are as follows:

First, problems and improvement opportunities for the clash detection process were derived in an objective manner by analyzing the procedure of clash detection, the participants in charge, requirements for and output of the process and by building an IDEFO model.

Second, the concepts of IPD and Lean Construction and relationship with the BIM model were understood, the direction of a BIM-based clash detection process was set by applying ECRS, and a plan for resolving the current problems was presented.

Third, a clash detection process was established based on these, and was expressed using a BPMN model to make it easy to understand for participants in the construction project and to induce its use in customized process building.

Although the considerations required for the smooth operation of the process were discussed in an FGI to obtain the full expectation of intended output and effects presented in this research, an 
analysis should be performed to achieve some improvements in the process after the process building and improvement are applied and operated in an actual site.

In addition, the BIM-based projects placed by the Public Procurement Service usually include design-bid-build, which has a drawback of being applied only to the design-build method. This research was focused on building a collaboration system for the clash detection process, and a more integrated collaboration system should be built to satisfy as many demands of participants as possible by establishing the process of quotation and process simulation for construction project management in the future.

\section{References}

1. Kim HS. Revealing Issues and Prospects of Domestic Construction by Analysis of BIM Case Studies. The Architectural Institute of Korea. 2010 Jan;54(1):65-9.

2. Shin TH. The Suggestion of the BIM Strategies for General Contractors. Journal of the Korea Institute of Building Construction. 2011 Apr;11(2):26-32

3. Kim CS. Effect and Prospect By BIM Case Study in the Construction Phase. The Architectural Institute of Korea. 2010 Dec;54(12):64-8.

4. Ministry of Land, Transport and Maritime Affairs. [The Guide of BIM Applications in Architecture]. Gwacheon (Korea): Ministry of Land, Transport and Maritime Affairs; 2010. 144 p. Korean.

5. Public Procurement Service. [The Primer of BIM Applications v1.0.] Daejeon (Korea): Public Procurement Service; 2010. 75 p. Korean.

6. Virtual Almighty. [The BIM Guideline version 2.0.] Seoul (Korea): Virtual Almighty; c2010. 75 p. Korean.

7. Kim JW, Ryu HK, Son BS, Choi YK. Business Process Model for Urban Regeneration Project using BPMN Modeling Method. Korea Institute of Construction Engineering and Management. 2010 Jul;11(4):41-50.

8. Kim BN, Kim TW, Kim HB, Lee YI, Lee KW. Exporting Business Process Modeling Using IDEFO and UML. Korea Intelligent Information System Society. 2001 Dec;7(2):179-93.
9. Kim MJ, Lee HG, Kim JJ. An Analysis of Management Process Using IDEFO. The Architectural Institute of Korea. 2006 Apr;22(4):177-85.

10. Allweyer T. [BPMN 2.0 Business Process Model and Notation]. 2nd ed. Park JY, translator. Ansan (Korea): Dbbada; 2009. 200 p. Korean.

11. Kim YS. New Paradigm of Project Delivery System for BIM based Construction Project. The Architectural Institute of Korea. 2010 Jan;54(1):37-40.

12. Eastman C, Teicholz P, Sacks R, Liston K. BIM Handbook. San Francisco (CA): Wiley John \& Sons International; 2009. $501 \mathrm{p}$.

13. Womack JP, Jones DT. Lean Thinking: Banish Waste and Create Wealth in Your Corporation. New York (NY): Simon \& Schuster; 2003. 400 p.

14. Kim YW, Kim KH. A Study on Preconstruction Process in Support of Lean Project Delivery System. Korea Institute of Healthcare Architecture. 2008 Nov;14(4):47-54.

15. Yoon YS. [Service Six Sigma]. 1st ed. Seoul (Korea): Nemo Sigma Group; 2003. 328 p. Korean. 